\title{
The Eurasian economic union: trends and prospects for development in digital economy
}

\author{
Anastasiya Vorona $^{1}$, Lyudmila Kopteva ${ }^{2, *}$, Anna Trushevskaya $^{3}$ \\ ${ }^{1}$ Saint-Petersburg branch of the Customs Academy, lit. A, 52, Sofijskaya str., 1912236, Saint \\ Petersburg, Russia \\ ${ }^{2}$ Saint-Petersburg State University of Aerospace Instrumentation, 67, Bolshaya Morskaia str., 190000, \\ Saint-Petersburg, Russia \\ ${ }^{3}$ Saint-Petersburg University of State Fire Service of Emercom of Russia, 149, Moskovskiy prospect, \\ 196105, Saint Petersburg, Russisa
}

\begin{abstract}
Currently the Eurasian Economic Union defines its main tasks as the creation of an image of the significant center for the development of international trade, enhancement of mutually beneficial partnership with member states and other countries, the creation of new formats for international cooperation. At the present days the Eurasian Economic Union is filled with real economic content. Multilateral projects are being implemented, primarily in key sectors of the economy, that are energy and transport. In the long run, the formation of a monetary union is possible. Development of currency integration, as a component of economic unity, presupposes the process of implementing a coordinated policy of the EAEU countries, as well as the creation and functioning of the organizations performing interstate currency regulation. In the article the dynamics of the main economic indicators of the Eurasian Economic Union functioning is considered. The data on the trade turnover of the EAEU member countries for 2019 is provided. The main directions of EAEU cooperation with third countries and integration associations are revealed, with particular attention being paid to the creation of free trade zones with Vietnam and Singapore. In the context of the organization and functioning of interstate unions, each of the member states of such unions, while ensuring their own security, also needs to manage both the threats to the security of other partners that have an indirect adverse effect and the threats that directly impact the whole union. The directions of digital transformation of the economies of the Eurasian Economic Union member states are considered. The problematic aspects of its functioning are highlighted.
\end{abstract}

\section{Introduction}

Under present-day conditions, the development of any state is impossible without integration processes. In this connection, any union of countries becomes relevant in order to create common borders and market with the purpose of its member - states economic

\footnotetext{
*Corresponding author: lusis63@mail.ru
} 
progressive development. Close attention deserves such an integration association as the Eurasian Economic Union (EAEU). The EAEU is an international organization of regional economic integration, which has international legal personality and was created as a result of the signing of the Treaty on the Eurasian Economic Union on May 29, 2014 [1].

EAEU is institutionalized with functions related to the formation of common external customs borders of its member countries as well as the development of a common foreign economic policy, setting of tariffs, prices and other components of common market functioning.

EAEU was created in full accordance with the principles of the United Nations Organization and international law as the assignee of the Customs Union. This is a clearly structured system with a definite mechanism for making and implementing decisions. It has international legal personality [2].

\section{Problem Statement}

The searching of ways of solution forthe problem of digitalization of all processes in the EAEU is highly relevant, due to the fact that economic situation in the EAEU member countries differs greatly from each other. The introduction of the latest technologies into government structures requires significant costs, the complexity is caused by the necessity to integrate new norms into legislation. Mentioned problems entail the need to review the existing mechanism of digital transformation of the EAEU member countries.

\section{Research Questions}

The subject of research is the digital transformation process taking place in modern conditions in the EAEU. Digital transformation is conditioned by the need for rapid electronic data exchange for the further implementation of the effective activities of the EAEU member states. At the same time, the use of digital technologies is the basis for the progressive development of interaction between the EAEU members.

\section{Purpose of the Study}

The purpose of the study is to analyze the trends and development prospects of the countries of the Eurasian Economic Union in the context of digitalization.

\section{Research methods.}

In the course of scientific research, methods of theoretical generalization and comparison, analysis and synthesis as well as methods of statistical analysis were applied.

\section{Findings}

The essence and development of integration is disclosed in the works of many scientists, such as E.V. Drobot, S.O. Kostyleva [3] (Drobot, Kostyleva, 2017), M.M. Matveev [4] (Matveev, 2015), E.P. Dobronravova [5] (Dobronravova, 2016), L.V. Sorokina [6] (Sorokina, Apanasenko, 2017) and others.

However, it is of scientific interest to study the stages of integration processes on the post-Soviet territory, as well as to explore the evolution of the regulatory framework in the 
field of customs of such an integration association as the Eurasian Economic Union [7] (Drobot, Ivko, 2018).

Currently the EAEU includes 5 countries: the Republic of Armenia, the Republic of Belarus, the Republic of Kazakhstan, the Kyrgyz Republic and the Russian Federation. The EAEU was created with the purpose to provide international cooperation and to increase the competitiveness of the economies that make up the union. In the EAEU freedom of movement of goods, services, capital and labor is ensured, as well as conducting of coordinated and unified economic policy for the comprehensive modernization, cooperation and increasing competitiveness of national economies in the interests of improving the living standards in member states.

In the course of its existence, the EAEU has created a huge array of supranational legislation that ensures the free movement of goods, services, and labor in a united economic space. The created Union actively influences the economic status of the participating countries, while economic indicators are growing.

Table 1. Economic indicators of the functioning of the EAEU for the period of 2015-2019 [8] (Source:http://www.eurasiancommission.org/ru).

\begin{tabular}{|c|c|c|c|c|}
\hline Year & $\begin{array}{c}\text { Mutual trade. } \\
\text { million US dollars }\end{array}$ & Changes. \% & GDP. \% & GDP. million US dollars \\
\hline 2015 & 45616 & & 98.1 & 1626772 \\
\hline 2016 & 42960 & 94.18 & 100.3 & 1487829 \\
\hline 2017 & 54712 & 127.4 & 101.9 & 1815785 \\
\hline 2018 & 60262 & 110.1 & 102.5 & 1914000 \\
\hline 2019 & 61034 & 101.3 & 101.6 & 1954200 \\
\hline
\end{tabular}

Based on the data mentioned in Tab. 01, it can be noted that since 2016 there has been a tendency to increase mutual trade between the EAEU member states, however, a slowdown in the growth of mutual trade can be clearly observed, as in 2019 it grew by $1.3 \%$ only compared to 2018.

Totally in 2019, the EAEU GDP increased by $1.6 \%$ compared to 2018 . As it can be observed in data in the Table 01, GDP has a positive trend since 2016. It is worth noting that the contribution of Kyrgyzstan to the total EAEU GDP is $0.4 \%$, which is the lowest level of indicator. The largest contributor is the Russian Federation, whose share is $86.5 \%$.

Ensuring macroeconomic sustainability and development is one of the priority tasks for the EAEU countries both at the national and supranational levels. For this, the Eurasian states need to stimulate business and investment activity. The EAEU countries are interested in attracting both internal and external investments. Eurasian integration is aimed to contribute to these processes, as well as to increase the investment attractiveness within the Eurasian Union.

In 2018, the EAEU investment in fixed assets amounted to 329,129 million USD; an increase of 5.6\% compared to 2017 and by $19 \%$ compared to 2015 (Tab. 02) was observed. At the same time, growth in investment in fixed assets was recorded in all the EAEU countries and the largest change in the value was performed by Kazakhstan, namely by $20.5 \%$.

Table 2. Investments in fixed assets of the EAEU for the period of 2015-2019, million USD.

\begin{tabular}{|l|c|c|c|c|}
\hline $\begin{array}{c}\text { States and } \\
\text { Associations }\end{array}$ & $\mathbf{2 0 1 5}$ & $\mathbf{2 0 1 6}$ & $\mathbf{2 0 1 7}$ & $\mathbf{2 0 1 8}$ \\
\hline Armenia & 1008 & 855 & 891 & 902 \\
\hline Belarus & 12745 & 9356 & 10879 & 12256 \\
\hline Kazakhstan & 31681 & 22686 & 26904 & 32430 \\
\hline Kyrgyzstan & 1975 & 1938 & 2109 & 2200 \\
\hline Russia & 229100 & 220461 & 274769 & 281341 \\
\hline
\end{tabular}




\begin{tabular}{|l|l|l|l|l|}
\hline EAEU & 276509 & 255296 & 315552 & 329129 \\
\hline
\end{tabular}

In 2019 the aggregate volume of trade turnover of the EAEU member countries with third countries amounted to 733.1 billion USD, including export of goods 459.3 billion USD and import 273.8 billion USD. Compared to January, in December 2018, the volume of foreign trade turnover decreased by $2.7 \%$ or 20.7 billion USD while exports decreased by $6.4 \%$ (31.4 billion USD), imports increased by $4.1 \%$ (by 10,7 billion USD). The foreign trade surplus amounted to 185.5 billion USD against 227.6 billion USD in the period from January to December 2018. The dynamics of export and import of the EAEU with third countries for the period of 2014-2019 is shown in Fig. 01. [9].

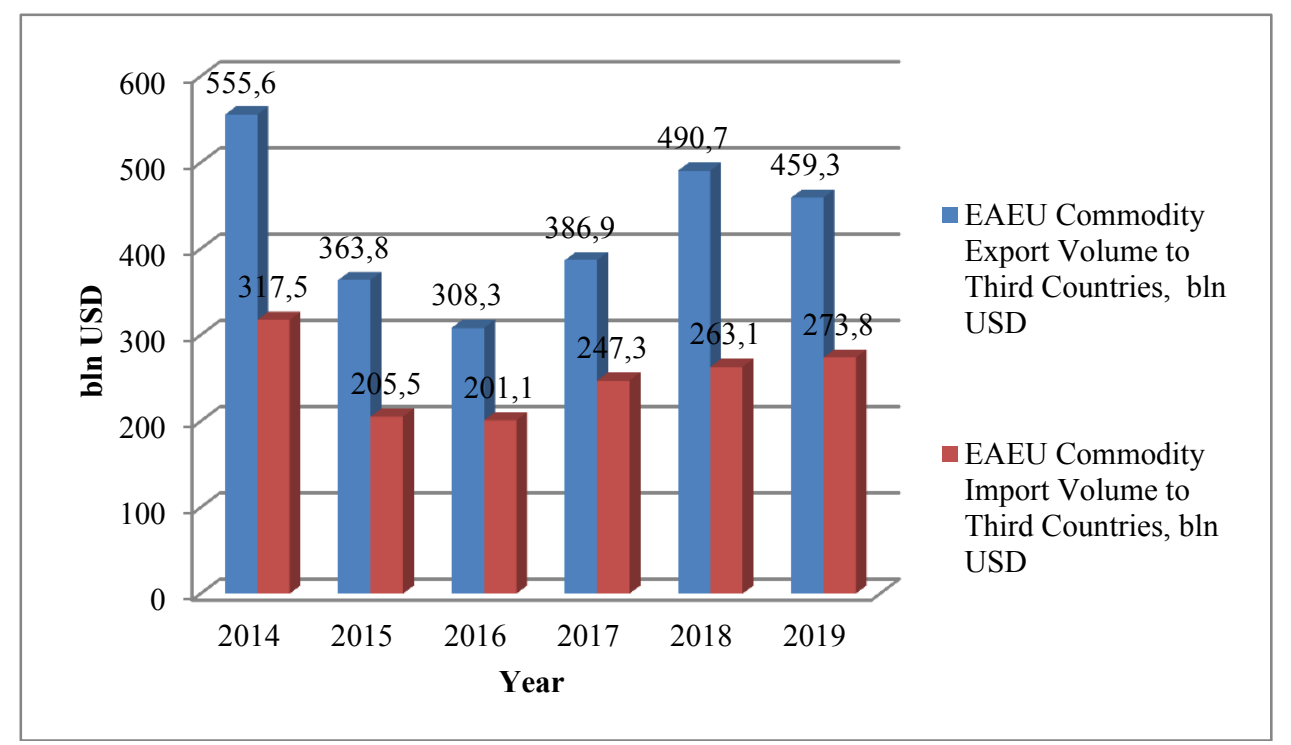

Fig. 1. Dynamics of export and import of the EAEU with third countries for the period of 2014-2019. Source: http://www.eurasiancommission.org/ [9].

In 2019 the aggregate volume of mutual trade in goods of the EAEU member states amounted to 61 bln USD. Fig. 02 shows the volume of intraregional export of the EAEU member states for 2015 and 2019. 


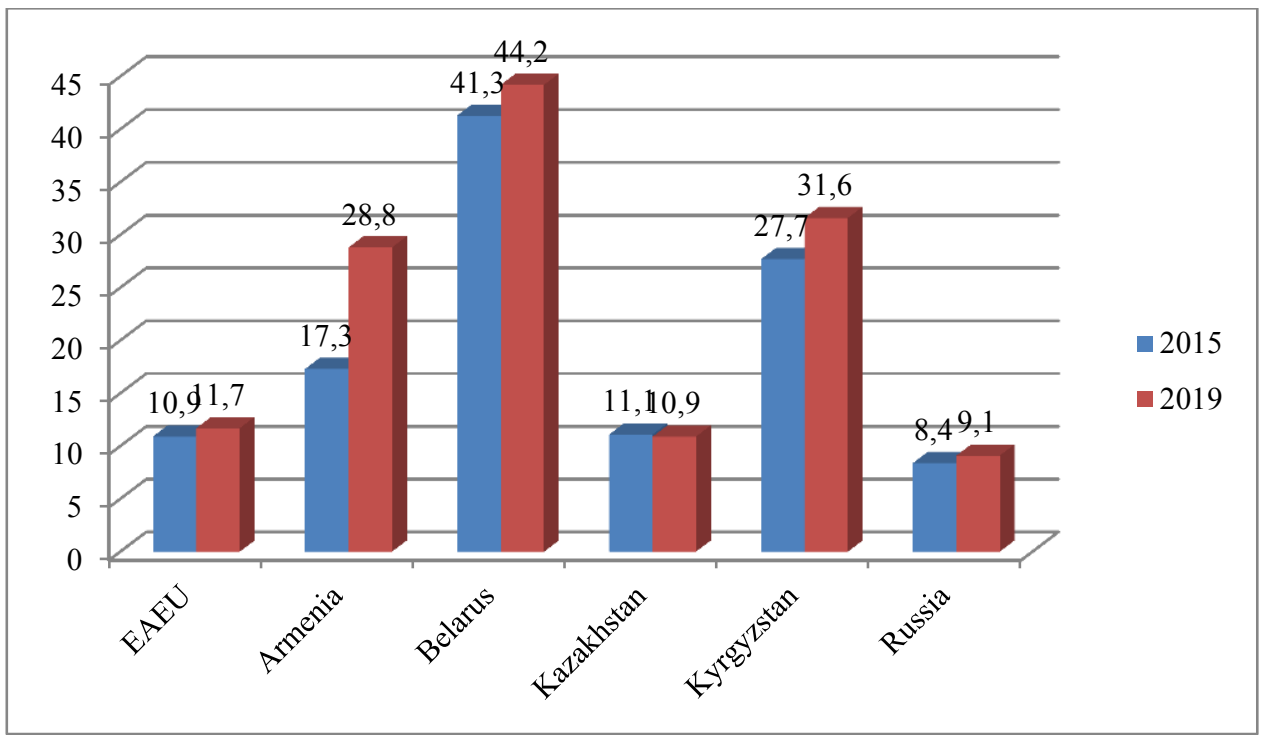

Fig. 2. The volume of intraregional export of the EAEU member states for 2015 and 2019, Source: http://www.eurasiancommission.org/ [9].

Fig. 03 shows the volume of intraregional import of the EAEU member states for 2015 and 2019.

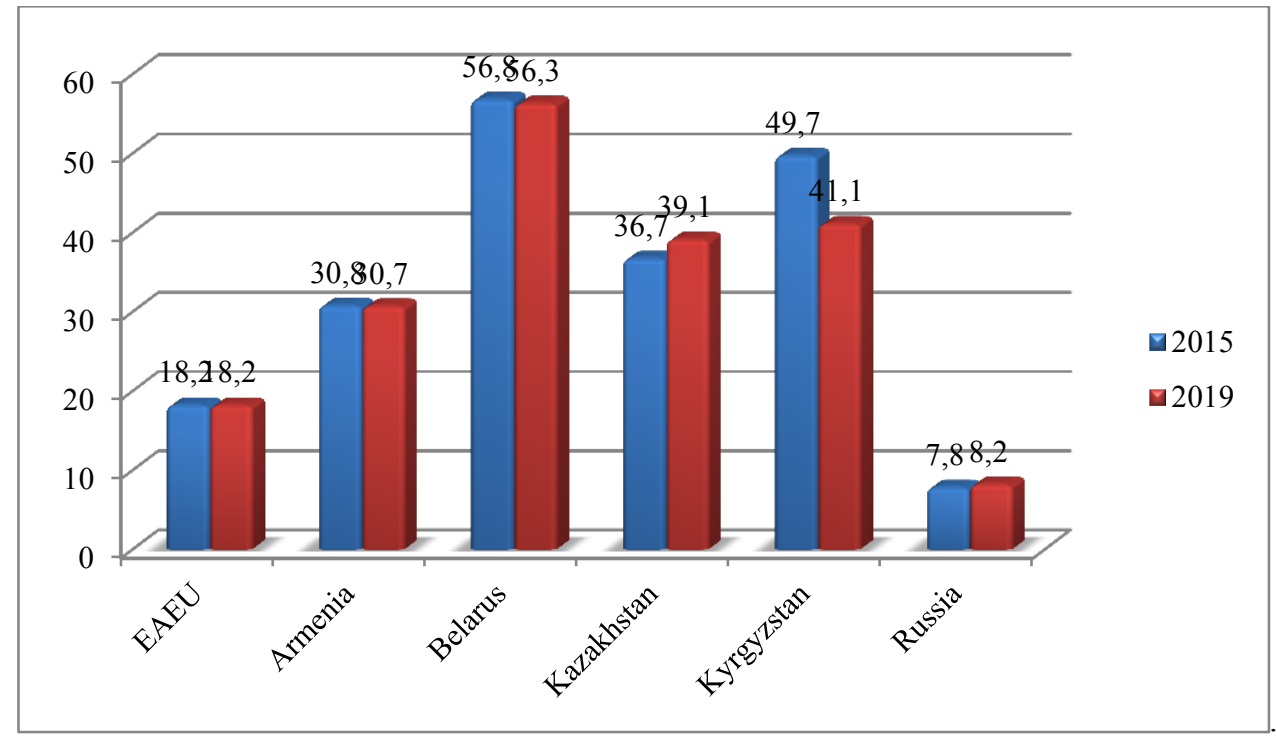

Fig. 3. The volume of intraregional import of the EAEU member states for 2015 and 2019. Source: http://www.eurasiancommission.org/ [9].

Based on the data presented in Figs. 02 and 03, the changes in the intraregional export and import of the EAEU member states do not change significantly, however, it is worth noting the sharp increase in the intraregional export of Armenia in 2019 compared to 2015 by $66.5 \%$.

The EAEU successfully develops cooperation with third countries and integration associations, forming a single space in which issues of interstate cooperation are clearly defined. Agreements have been concluded on the formation of a free trade zone (FTZ) with 
Vietnam, Singapore, Serbia (unification of the trade regime within the Union), Iran (interim agreement leading to the formation of a free trade zone). At the stage of negotiations are agreements with Israel, Egypt and India.

Over the five years of the EAEU's existence, memorandums have been undersigned with Singapore, Cambodia, the Republic of Korea, Chile, Mongolia, Greece, Peru, Jordan, Morocco, Cuba, Ecuador and several other countries. As well the EAEU has valid agreements with the world's largest integration associations, including ASEAN, MERCOSUR, the Latin American Economic System, the Andean Community, and the CIS.

For the successful and optimal implementation of all the goals and objectives of international activities, it is necessary to expand geographical borders, increase export volumes, create new trade relations and partnerships, maintain and strengthen already established ties, attract foreign investment and technology for economic development [10].

Any external partner contributes to the development of national economies and the strengthening of the EAEU markets, that's the reason the Union seeks to expand quantity of such partners. In this connection the details of the EAEU integration prospects should be considered. A free trade zone has been operating between the EAEU and Vietnam since 2016. The EAEU exports meat and dairy products, wheat, flour, cereals, alcohol and cigarettes, petroleum products, automobiles, tires, steel pipes, fertilizers. Vietnam offers for export fish, rice, fruits, vegetables, nuts, clothes, sports shoes, leather goods, household manufactured goods, electronic equipment. Since the entry into force of the trade agreement between Vietnam and the Eurasian Economic Union in 2016, the growth rate of trade between Vietnam and the Russian Federation has increased significantly, with an average of $30 \%$ per year. Russia accounts for more than $90 \%$ of total trade between Vietnam and the EAEU. In the period from 2015 to 2018, the total turnover between Russia and Vietnam increased by 2221.6 million US Dollars. In 2019, the trade between Russia and Vietnam amounted to 4,919.1 million US Dollars [11]. At the same time, the share of imports significantly exceeded the share of exports and amounted to $77 \%$. The signing of the Free Trade Zone agreement contributes to the growth of trade between its participants, and also helps to strengthen trade and economic ties due to the simplified regime of goods turnover. All this becomes a prerequisite for the EAEU to join dynamically developing integration processes on the territory of the Asia-Pacific region. The signing of the agreement affected the growth of mutual trade and, as a result, contributed to a number of positive effects for business structures.

The greatest interest calls the free trade zone with Singapore. On October 1, 2019, during the meeting of the Supreme Eurasian Economic Council, the Free Trade Agreement and the Framework Agreement on Comprehensive Economic Cooperation between the EAEU Member States and Singapore were signed. The economy of Singapore operates in a "free port" mode: customs duties are applied only to imported vehicles, alcoholic beverages, tobacco products and petroleum products. Singapore is one of the leading economies in the world, one of the world's major ports and logistic hubs. Cooperation with the republic allows member states to significantly increase export flows. In addition, cooperation with Singapore will enable the EAEU countries to establish trade relations with all members of the Association of Southeast Asian Nations (ASEAN), since the country is one of the most important members of ASEAN. A promising area is also investment cooperation between Singapore and the EAEU countries. An additional advantage from cooperation with Singapore is possibility to cooperate new technology platforms. In particular, in the framework of the implementation of the EAEU digital agenda until 2025, the task of integrating Eurasian digital ecosystems into global ones is outlined. Singapore in this regard can be considered as an entry point for further interfacing of the EAEU systems 
and ASEAN countries. One of the industry leaders, Singapore's vCargo Cloud, has wide experience in automating logistics services around the world.

For the ASEAN countries, the development of cooperation with the EAEU countries is a logical complement to the efforts already underway to form stable and mutually beneficial ties with partners in the Eurasian territory, to consolidate the role of ASEAN as one of the leading factors in the framework of integration processes in Eurasia. For the EAEU members, the possible formation of a free trade zone with ASEAN not only opens up new sales markets, sources of investment and investment opportunities, but also provides an opportunity to include national industry and individual industries in international production chains functioning and being formed with the participation of ASEAN member countries (Vorona, 2020) [12].

On October 27, 2019, an Interim Agreement was signed with Iran on joining the EAEU Free Trade Zone, so that becomes possible to either completely abolish duties or significantly reduce them for export of 502 items of its goods. This agreement covers $50 \%$ of the volume of mutual trade and, according to analysts, should contribute to the generation of income by Russian business of 150 million US Dollars annually. EAEU countries export to Iran mainly meat and fat products, confectionery, chocolate, metals, cosmetics, and some types of electronic and mechanical equipment. In response, Iran supplies vegetables, fruits, dried fruits, building materials, carpets, some non-ferrous metal products and utensils to the EAEU market. The free trade agreement between the EAEU and Iran will certainly open up new opportunities for increasing the volume of Iranian trade. Iran is gaining free access to a market with 183 million people and gross domestic product of more than 4 trillion US Dollars. All of these will contribute to deeper integration of the EAEU member countries, simplification of trade relations and stimulation of the implementation of other projects, including such a huge one as the Chinese "One Belt - One Road". Joining the EAEU Free Trade Zone is a very important step especially in the conditions when the USA continues the policy of maximum pressure on the Islamic Republic. Joining the EAEU ensures a smooth connection of Iran to the global economy, contributes to the prosperity of the national economy, increase its competitiveness on the world stage.

With the other countries mentioned above at the moment only negotiations are underway, the longest of them are negotiations with Israel, they have been ongoing since 2015. Israel is one of the most promising trading partners due to the fact that at the moment this state is actively and dynamically developing. Israel, although it is not a large state with which there are certain limits to mutual trade cooperation, is showing dynamic development and is a promising ally of the EAEU in economic development. To do this, it is only necessary to clearly regulate the terms of all agreements between countries in order to achieve mutually beneficial relations, as well as to shift the structure of traditional commodity nomenclatures towards the trade in services.

The economies of the EAEU member states showed growth in 2019, however, in Russia and Belarus there is a tendency to slow down due to a shortage of investment in fixed assets and retail.

In general, the important stage in the formation and development of the EAEU is digitalization of the economies of the member states. In this regard, on October 11, 2017, the heads of the EAEU Member States approved the Main Outline for the Implementation of the Digital Agenda until 2025 [13].

The directions of development of the digital economy within the framework of this document include the following tasks: digital transformation of economic sectors and crossindustry transformation;digital transformation of markets for goods, services, capital and labor;digital transformation of management processes and integration 
processes;development of digital infrastructure and ensuring the security of digital processes.

For the implementation of the Digital Agenda, an Integrated Information System was created. The system is designed for rapid interstate exchange of data and electronic documents within the EAEU, the creation of common information resources for member states, the implementation of common processes, as well as the support of the activities of the EAEU bodies.

The development of an integrated system will provide new opportunities for the formation of digital platforms using common data models and a single system of normative and reference information of the Union. In this regard, on August 9, 2019, the Concept of cross-border information interaction was adopted [14]. This Concept defines general approaches to organizing the information interaction of legal entities (business entities) of the EAEU member states with each other and with authorized bodies.

The main advantage of the integrated system is its cross-sectoral nature and scalability with the possibility of expansion of regulatory areas in the EAEU and information interaction with third countries and other integration associations.

The state information resources and information systems of the authorized bodies of the Member States are connected to the integrated system through national integration gateways as part of the implementation program of common processes in the Union.

In fact, through the creation of the Union's Integrated Information System, the compatibility of various information systems in different countries is ensured. This problem has been resolved in the legal field, methodologically and technically.

Moreover, within the framework of the Integrated Information System on the basis of a unified methodology for information integration and the EAEU data model, a cross-border trust space has been created and is being maintained, providing a technical infrastructure, 14 subsystems and 7 national and supranational integration gateways, more than 80 directories and classifiers, more than 6 thousand information objects in the EAEU data model for 11 areas of regulation. Publicly accessible open data services have been formed for information resources. On the issues of the integrated system, more than 100 legal acts of the EAEU bodies have been adopted.

At the present stage, the Board of the EAEU has digitized and put into operation three more processes of interstate (cross-border) electronic interaction systems in the customs sphere, as well as the process in the field of customs-tariff and non-tariff regulation. Data on these processes will be transmitted and processed by means of the IIS of the Union. The introduction of these processes will contribute to the effective planning and organization of foreign economic activity in logistic operations by participants, as well as to the acceleration and simplification of customs procedures related to the import of certain types of goods.

Since the beginning of 2020, during the implementation of common processes between the EAEU countries and the Commission, more than 8 million electronic messages have been transmitted and processed as part of the information interaction between government bodies. For the EAEU countries that cannot quickly finalize creation of their systems, free software is provided to perform the basic functions of the common processes.

The use of implemented common processes will allow organizing an operational electronic exchange between the authorized bodies of the countries and the Commission for the formation and maintenance of a list of checkpoints and a database of passport checkpoints across the external border of the Eurasian Economic Union.

However, in addition to the positive aspects of the functioning of the EAEU, problematic aspects also can be distinguished. Among the key problems of the EAEU, it is worth noting the persistence of non-tariff barriers in the markets for goods and services, the lack of mechanisms to stimulate production cooperation and clustering, as well as the 
inability to replenish the Union budget through customs duties of the common customs tariff and foreign trade taxes (excise duties, VAT).

In addition, the need to introduce a single currency has been discussed for a long time. It is believed that "Altyn" or "Evraz" could be a worthy response to the dollar and can simplify mutual settlements. But there is another opinion, negative one, regarding this debatable question as some countries can become financially dependent on stronger ones.

At the present stage the EAEU has not formed acceptable conditions for monetary and financial integration, in addition, there are problems in the economic integration of the participating countries due to various levels of their economies development and instability of the national currencies.

Hence, the EAEU Member States should re-evaluate integration development strategies, develop a lending model and an economic development plan to align national economies, in addition, to elaborate a plan for coordinating activities in the currency sector (Kopteva, Kashintseva, 2019) [15].

Also a problematic question is the slow harmonization of many issues at the national level. Namely, the document on the pension provision of labor migrants in the union space has not yet been adopted. The Kyrgyz Republic has certain problems with the creation of a sufficient number of phyto- and veterinary laboratories necessary for quality control performance. At the same time, it should be noted that these problems can be resolved through negotiations between the parties.

In addition to the above, the issues of the development of the EAEU include the issue of elimination of goods smuggling from third countries (EU, China), as well as emerging trade conflicts between the EAEU members.

\section{Conclusion}

Thus, for the successful development and further integration of the EAEU, it is necessary to create integration associations, such as free trade zones, to strengthen control over trade and eliminate the problematic aspects of the functioning of the Union. In this regard, the need for improving the digital technologies is increasing. The EAEU digital agenda is becoming not only integrational, but also the national agenda of the member states of the Union, and is the most important factor in the implementation of interstate economic projects.

\section{References}

1. Treaty on the Eurasian Economic Union (Signed in Astana May 29, 2014) (ATP Consultant Plus), http://www.consultant.ru/document/cons_doc_LAW_163855/

2. EurAsEC in questions and answers, http://www.evrazes.com/about/questionanswer

3. E.V. Drobot, S.O. Kostyleva, Russian Journal of Entrepreneurship 1, 23-40 (2017) Doi: 10.18334 / rp.18.1.37212

4. M.M. Matveev, Economics, entrepreneurship and law 2, 73-78 (2015)

5. E.P. Dobronravova, Audit and financial analysis 5, 48-57 (2016)

6. L.V. Sorokina, M.M. Apanasenko, Trade and Economic Journal 4 (2017)

7. E.V. Drobot, E.S. Ivko, Ekonomicheskie otnosheniya 8(3), 293-314 (2018) Doi: 10.18334 / eo.8.3.39163

8. A.V. Bataev, A.A. Gorovoy, A.B. Mottaeva, Proceedings of the 32nd International Business Information Management Association Conference, IBIMA 2018 - Vision 2020, 102-114 (2018) 
9. ECE official website, section "Statistics of foreign and mutual trade in goods" (2019) http://www.eurasiancommission.org/

10. A.V. Bataev, A.B. Mottaeva and E.Y. Vasilyeva, Proceedings of the 34th International Business Information Management Association Conference (IBIMA)-2019, Vision 2025: Education Excellence and Management of Innovations through Sustainable Economic Competitive Advantage 14015, 277-287 (2019)

11. FCS official website, http://customs.ru/statistic/

12. A.A. Vorona, Uchenye Zapiski Sankt-Peterburgskogo imeni VB Bobkova branch of the Russian Customs Academy 1(73), 51-54 (2020)

13. Decision of the Higher Eurasian Economic Council dated 11.10.2017 No. 12 "On the Main Directions for the Implementation of the Digital Agenda of the Eurasian Economic Union until 2025" (ATP "Consultant Plus")

14. Decision of the Eurasian Intergovernmental Council dated 08.09.2019 No. 7 "On the Concept of Cross-Border Information Interaction", http://docs.cntd.ru/document/560943025

15. L.A. Kopteva, V.A. Kashintseva, IOP Conf. Ser.: Earth Environ. Sci. 403, 012224 (2019) https://doi.org/10.1088/1755-1315/403/1/012224

16. A.V. Bataev, A.A. Gorovoy, A.B. Mottaeva, Proceedings of the 32nd International Business Information Management Association Conference, IBIMA 2018 - Vision 2020, 88-101 (2018)

17. G. Semenova, On the Horizon 27(3/4), 213-218 (2019) https://doi.org/10.1108/OTH07-2019-0035 